NBER WORKING PAPER SERIES

THE RECOVERY FROM THE GREAT RECESSION: A LONG, EVOLVING EXPANSION

\author{
Jay C. Shambaugh \\ Michael R. Strain \\ Working Paper 28452 \\ http://www.nber.org/papers/w28452
}

\author{
NATIONAL BUREAU OF ECONOMIC RESEARCH \\ 1050 Massachusetts Avenue \\ Cambridge, MA 02138 \\ February 2021
}

This paper was prepared for a special issue of The ANNALS of the American Academy of Political and Social Science, "What has happened to the American Working Class since the Great Recession?" We thank Duncan Hobbs for excellent research assistance. The views expressed herein are those of the authors and do not necessarily reflect the views of the National Bureau of Economic Research.

NBER working papers are circulated for discussion and comment purposes. They have not been peerreviewed or been subject to the review by the NBER Board of Directors that accompanies official NBER publications.

(C) 2021 by Jay C. Shambaugh and Michael R. Strain. All rights reserved. Short sections of text, not to exceed two paragraphs, may be quoted without explicit permission provided that full credit, including (C) notice, is given to the source. 
The Recovery From The Great Recession: A Long, Evolving Expansion

Jay C. Shambaugh and Michael R. Strain

NBER Working Paper No. 28452

February 2021

JEL No. E24,E3,E6,J3

\begin{abstract}
$\underline{\text { ABSTRACT }}$
Prior to 2020, the Great Recession was the most important macroeconomic shock to the United States economy in generations. Millions lost jobs and homes. At its peak, one in ten workers who wanted a job could not find one. On an annual basis, the economy contracted by more than it had since the Great Depression. A slow and steady recovery followed the Great Recession's official end in the summer of 2009, but because it was slow and the depth of the recession so deep, it took years to reduce slack in labor markets. But because the slow-and-steady recovery lasted so long, many pre-recession peaks were exceeded, and eventually real wage growth began to accumulate for workers across the distribution. In fact, the business cycle (including recession and recovery) beginning in December 2007 was one of the better periods of real wage growth in many decades, with the bulk of that coming in the last years of the recovery. We place the Great Recession in historical context and trace the path of the recovery, studying its different phases and how different groups of workers were impacted in each phase. We also discuss the response of fiscal and monetary policy to the Great Recession, and draw lessons for the future.
\end{abstract}

Jay C. Shambaugh

George Washington University

Elliot School for International Affairs

1957 E Street, N.W. Suite 502D

Washington, D.C. 20052

and NBER

jshambaugh@gwu.edu

Michael R. Strain

American Enterprise Institute

1789 Massachusetts Avenue, NW

Washington, DC 20036

and IZA

michael.strain@aei.org 


\title{
The Recovery From The Great Recession: A Long, Evolving Expansion
}

\author{
Jay C. Shambaugh and Michael R. Strain*
}

\section{Introduction}

Prior to 2020, the Great Recession was the most important macroeconomic shock to the United States economy in generations. Millions lost jobs and homes. At its peak, one in ten workers who wanted a job could not find one. On an annual basis, the economy contracted by more than it had since the Great Depression. Asset prices fell sharply. Policy interest rates hit their lowest level in history, and deficits spiked. The jury is still out on the severity and lasting duration of the Pandemic Recession, but it would not surprise us if history remembers the Great Recession as the more significant macroeconomic event of the two.

A slow and steady recovery followed the Great Recession's official end in the summer of 2009 , but because it was slow and the recession was so deep, it took years to reduce slack in labor markets. Despite steady job growth, the share of the population that was employed stayed well below pre-recession levels for years, and wages grew slowly.

But because the slow-and-steady recovery lasted so long, many pre-recession peaks were exceeded, and eventually real wage growth began to accumulate for workers across the distribution. In fact, the business cycle (including recession and recovery) beginning in

\footnotetext{
* Shambaugh: George Washington University; jshambaugh@email.gwu.edu. Strain: American Enterprise Institute; michael.strain@aei.org. This paper was prepared for a special issue of The ANNALS of the American Academy of Political and Social Science, "What has happened to the American Working Class since the Great Recession?" We thank Duncan Hobbs for excellent research assistance.
} 
December 2007 was one of the better periods of real wage growth in many decades, with the bulk of its gains coming in the last years of the recovery.

Despite eventual gains for workers, the longest expansion in U.S. history featured slow productivity growth and slower output growth than many expected. It was supported by accommodative monetary policy for an extended period. Fiscal policy was more variable, supportive early in the recovery before pivoting to a contractionary stance, and then featuring a surge of deficit spending late in the expansion.

The economic expansion following the Great Recession included the longest streak of job growth on record. Beginning in October 2010, the economy added jobs for 113 consecutive months. The streak ended in March 2020 when the COVID-19 recession began.

The length of the expansion allowed it to go through different phases. Early in the expansion, jobless rates remained stubbornly high, participation rates continued falling, and wage growth was slow. Compared to their outcomes prior to the recession, the least-educated, lowest-wage workers in the labor market fared considerably worse than more-educated, higherwage workers.

But by 2014, wages began to grow faster at the median. By 2015, prime-age labor force participation began to increase. In the last five years of the expansion, wage growth had picked up at the bottom of the income distribution, outpacing gains in the middle and at the top of the distribution. Employment rates for the workers with the least education rose further above their pre-recession level than those for college graduates. Vulnerable workers saw their labor market prospects improve considerably. The length of the expansion — which allowed the labor market 
to tighten — was critical to both bringing people back into the workforce and seeing wage gains pushed across the income distribution.

The length of the expansion, and continual job growth, highlights in some sense how long the economy had extensive labor market slack. The loss of jobs in the first two years following the start of the recession (peaking at 8.7 million jobs), the increase in the unemployment rate by 5.3 percentage points, and the decline in participation were so stark during the financial crisis that there was a large amount of labor market slack when positive job growth did begin. In addition, the financial crisis struck when there was arguably still labor market slack following the 2001 recession. ${ }^{1}$ The combination of the challenges monetary policy faces when at the zero lower bound, a too-soon pivot to fiscal austerity, and crisis and slow growth around the world all contributed to a recovery that did not reach anything close to full employment for years and that left the bottom half of workers behind for years. But in the second half of the recovery, when more slack had been absorbed, gains were broadly shared.

\section{Background: The pre-Financial Crisis Labor Market}

From 1979 to 2007 , the U.S. economy experienced five recessions, two long expansions (83-90 and 91-01), and one relatively shorter expansion (02-07). Unlike earlier periods, the economy had labor market slack — defined here as an unemployment rate above the CBO’s

\footnotetext{
${ }^{1}$ Employment did not grow sufficiently from 2001-2008 to bring employment rates back to their pre-recession levels. See Schanzenbach, Nunn, Bauer, and Breitwieser (2017).
} 
estimate of full employment - for most of that time. ${ }^{2}$ The only exceptions were the concluding years at the end of each of the three periods of economic expansion. ${ }^{3}$

This labor market slack likely contributed to the fact that wage growth was often sluggish when compared to overall economic growth. In addition, what wage growth took place was generally unequally distributed such that median wages - and especially wages for those at the bottom of the income distribution - saw relatively little gains from 1979 to the 1990s. In fact, average real wages for production and nonsupervisory workers were declining for much of the 1980s (and 1970s).

The situation changed beginning in the 1990s, which witnessed wages growing, not declining. Real wages for nonsupervisory workers increased by 18 percent during the 1990's and 2000’s business cycles (July 1990 to December 2007). During the 1990's business cycle, real wages grew a rapid 1.1 percent per year followed by 0.7 percent per year from March 2001 to December 2007. ${ }^{4}$ Median wages, as well as wages at each decile below the median, increased over this period as well. ${ }^{5}$

\footnotetext{
${ }^{2}$ The estimated full-employment unemployment rate, also referred to as the long-run unemployment rate or NAIRU (non-accelerating inflation rate of unemployment), refers to the unemployment rate at which there is neither slack in the labor market nor upward pressure on inflation due to output growth being persistently above its underlying sustainable pace. It is the theoretical unemployment rate below which we would expect sustained price inflation. The NAIRU does not equal zero as there is always some churn in the labor market. The Congressional Budget Office (CBO) publishes its estimated long-run rate.

${ }^{3}$ See Bernstein (2018). Beyond the narrow definition of labor market slack used in that calculation, we use it more broadly to mean a period of time where there is insufficient demand for labor such that many people who would work if the economy were operating at full strength are without a job, either formally unemployed or having dropped out of the labor force entirely.

${ }^{4}$ This deflates average hourly earnings for production and non-supervisory workers by the price index for personal consumption expenditures (PCE). Using the consumer price index instead would show slightly slower real wage growth over this period (a total of 7 percent). Following the Congressional Budget Office and Federal Reserve, we use the PCE for all inflation adjustments in this paper. See Strain (2020) for a discussion of the merits and drawbacks of each.

${ }^{5}$ See Figures 7 and 9 in Strain (2020).
} 
These gains were not enough to reverse the long-running trend in labor force participation for prime-age men, which continued its decline. Participation started falling in the late 1950s and continued for decades leading to the Great Recession. The drop was particularly steep for prime-age men with less education (CEA 2016). ${ }^{6}$ Even in periods of economic strength - like the 1990s expansion - male prime-age participation was lower at the end of the expansion than it was at the start.

In contrast, women's prime-age labor market participation rose steadily from the 1950's to the late 1990s. The combination meant that overall prime-age participation was at a high in 1999 of 84.1 percent, far above the 77.9 percent in 1979. After the 2001 recession, though, women's prime-age participation began to trend down alongside men's, such that overall participation was more than a point below its 1999 level when the Great Recession struck. This incomplete recovery in the labor market from the 2001 recession meant that there was still arguably slack in the U.S. labor market when the Great Recession began.

In addition, substantial gaps in regional outcomes (especially across places with different levels of education $)^{7}$ and a large and growing difference in returns for those with higher education relative to those without, as well as large racial wage gaps all meant that on the eve of the Great Recession many of the most vulnerable in the labor market were already facing relatively weak labor market prospects and outcomes.

\footnotetext{
${ }^{6}$ This combination of falling labor force participation and sluggish or declining wage growth for men with lesser education suggests a drop in labor demand for male workers with less education. See CEA (2016).

${ }^{7}$ See Nunn, Parsons, and Shambaugh (2018) for a discussion of the large gaps across regions and Russ and Shambaugh (2019) for a discussion of the growing segmentation of the labor market across counties with different levels of education.
} 


\section{The Great Recession: Leaving a huge hole in the labor market}

To understand the 2010's recovery, it is essential to have the context of the unusual depth of the hole in the economy caused by the financial crisis and Great Recession. The recession built slowly in many ways. While it technically started in December of 2007, output had fallen just 0.8 percent at an annual rate in the first three quarters of 2008 . Then, after the failure of Lehman Brothers and subsequent financial shocks, output collapsed in the $4^{\text {th }}$ quarter of 2008, dropping more than 2 percent in just that quarter (over 8 percent at an annual rate). In total, by the time output stopped falling, GDP had contracted roughly 4 percent in total from its peak.

Table 1 below contrasts major macro indicators in this recession/recovery with the prior three business cycles. The table documents its depth. The Great Recession was a notably larger shock than any of the recent recessions, even the 1981-2 recession that sent unemployment over 10 percent had a lower GDP loss, a smaller spike in the unemployment rate, and a smaller loss of employment. The recession was also clearly longer. The length of time to recover employment and the time it took to return to CBO's natural unemployment rate were notably longer for the recovery from the Great Recession than for the other three expansions.

The shock to labor markets was in many ways worse than the loss of output. The loss of employment (8.6 million jobs, or 6.3 percent of prior peak) was massive, roughly twice as bad as prior recessions. The 1982 recession had a maximum job decline of 2.8 million (3.1 percent of peak); the 1991 recession had a drop of 1.5 million jobs (1.4 percent of peak) and the 2001 recession had a loss of 2.6 million jobs (2.0 percent of peak.) Figure 1 shows the depth of the shock in sharp relief. 
This employment drop from peak to trough (6.3 percent) was notably larger than the output drop (4.0 percent). In addition, unemployment rates spiked, doubling and briefly rising to 10 percent. The more rapid drop for employment than output generated some odd statistical quirks. Labor productivity growth was strong at first as output fell less than hours worked. The compositional shift in which workers were still employed meant that wages actually rose - with average hourly earnings of production and non-supervisory workers continuing to grow at roughly 4 percent a year (the same as their pace in the prior two years) despite the massive shock and extensive slack in labor markets. ${ }^{8}$

The financial crisis was of course far more broad than just its macroeconomic aggregate outcomes. ${ }^{9}$ Equity prices fell by more than half from the start of the recession to early March 2009, home prices which had already been falling for a year prior to the recession fell more than another 20 percent after the beginning of the recession, and overall, net worth of households declined 12 percent from the quarter prior to the recession to the quarter after, as shown in Figure 2. ${ }^{10}$ In the prior three recessions, net worth continued to grow (albeit slowly) over the course of recessions. This substantial blow to the wealth of consumers helped cast a long shadow over the recovery Over the next few years, households underwent substantial deleveraging both by defaulting on some obligations and accumulating less debt as their incomes rose, continuing to act as a brake on consumption and other spending. This was a substantial headwind to growth that is common in financial and housing crisis triggered recessions (Jorda, Schularick, and Taylor, 2015).

\footnotetext{
${ }^{8}$ See Daly and Hobijn (2017).

${ }^{9}$ See Ziliak (2021) for a discussion of the broader deterioration of material well-being of households during the Great Recession including rising food insecurity and falling home ownership.

${ }^{10}$ See Addo and Darity (2021) for a discussion of changes in wealth over the course of the 2010's expansion looking across race and class.
} 


\section{Recovery}

The recovery from the Great Recession is defined by two characteristics. It was the longest expansion in modern U.S. macroeconomic history, with both the longest positive job streak on record and an output expansion (measured in change over four quarters) that lasted over a decade. At the same time, the expansion was quite slow. In the previous 3 recessions, it took 5-6 years for the unemployment rate to fall to the CBO's estimate of the natural rate of unemployment. Following the Great Recession, it took over 9 years for the economy to reach that point, as shown in Figure 3. ${ }^{11}$

There are many other ways to see the extensive slack in the labor market, beyond the unemployment rate. Figure 4 shows that labor force participation fell for a number of years. For prime-age workers, it was on a downward trend until the fall of 2014, around 7 years after the start of the recession.

In many ways, the continual solid job growth that characterize the expansion was itself a sign of the labor market slack. Job growth was consistently above the growth of the working age population, as shown in Figure 5, indicating that there were additional people able to work that had not been previously working, month after month.

Low levels of inflation and nominal wage growth also indicate slack. If there really were structural shifts that had increased the long run level of the unemployment rate or lowered the

\footnotetext{
${ }^{11}$ In part this time represents a lower estimate for the natural rate by CBO in the mid to late 2010's (4.5\%) than in the 1980 s or $1990 \mathrm{~s}(6.0 \%$ and $5.5 \%)$. But, following the 1982 recession, it took just 35 months to get to the prerecession level and the 1991 recession took 74 months. This contrasts with the expansion following the Great Recession when it took 108 months. The 2001 recession is the outlier in that it started at such a low rate (4.2\%) it in fact never returned to that level prior to the next recession starting.
} 
long run equilibrium prime-age employment rate, then the continued job growth would have put upward pressure on wages and prices. And yet, both inflation and nominal wage growth were unusually low in this recovery.

The inflation rate almost never breeched $2 \%$ during the expansion, and the growth rate of average hourly earnings of production and non-supervisory workers, which had been roughly 4 percent a year prior to the recession, fell to 2.4 percent by the end of 2009 , down below 2 percent by the end of 2011, and did not rise above 3 percent until late 2018, over a decade after the recession began. At no time during the recovery was this crucial measure of wage growth for typical workers above 4 percent. This low wage growth and inflation suggests that capacity constraints or structural mismatch ${ }^{12}$ were not holding back the recovery, but rather that there was extensive slack for the economy to absorb.

Figure 6 shows average wages of production and nonsupervisory workers as well as "core" PCE inflation (the change in prices in the personal consumption expenditure index excluding volatile energy and food prices, the preferred measure of the Federal Reserve) and overall PCE inflation. The low level of the orange line - consistently below 2 percent highlights the lack of price pressure. Similarly, the low level of nominal wage growth, especially contrasted with earlier eras, highlights the lack of nominal wage pressure.

The contrast between the overall price index and wage growth, though, makes another fact about this recovery interesting. Real wage growth was surprisingly strong. In fact, as shown in Table 2 below, average real wage growth in this business cycle overall (including the recession and expansion) was higher than in any other recent business cycle except the 1990s,

\footnotetext{
${ }^{12}$ See Lazear and Spletzer (2012) for an analysis of the limited role of structural unemployment in the early years of the recovery from the Great Recession.
} 
and real wage growth for production and non-supervisory workers was actually larger in this business cycle than even the 1990s (13 percent versus 12 percent). This is also abundantly clear from the figure. In the 1980s, wages and prices often tracked very close together leaving almost no real wage growth. This was true in the early 1990s as well. In contrast, the mid 1990s began a period of extended real wage growth.

The 2010's expansion also had long periods of real wage growth. Unlike the late 1990s, the real wage growth was initially more a feature of very low price growth (due to energy prices as can be seen in the dip in overall prices but not core prices). But beginning in 2012 and then especially in 2014 forward, nominal wage growth consistently exceeded price inflation, leaving plentiful real wage gains.

The figure also makes clear the extent to which some of these relationships were changing late in the expansion. Nominal wage growth first ticks up in 2015 (no coincidentally when the unemployment rate was nearing CBO's natural rate and labor force participation began to rise), and then picks up again in 2018 .

Table 2 documents productivity, inflation, and wages during the full business cycle following the beginning of each recession. Perhaps the most notable fact about this recovery is its length. The 2010's expansion following the Great Recession was the longest economic expansion in recent memory, longer that the long expansions in the 80's and 90's and nearly twice as long as the 2000's expansion that preceded it. That length allowed for gains to accumulate over time such that the real average wage gains were three times as large as in the 80's or 00's and nearly as large as the highly successful labor market of the 1990's. That is, despite the frequent concerns that it did not provide good returns to workers, by the end of the recovery, it had been a successful period for workers - on average. Clearly, those gains were 
slower on an annual basis, but even measured in that way, real wage gains were greater than in the expansions of the 1980s or 2000s.

Productivity, on the other hand, was notably slower in this recovery. Growth in output per hour worked (measured peak to peak) was well below that of the prior three business cycles. Scholars of productivity often note different eras of productivity growth booms and the last one from 1995-2004 generated good productivity gains in the 90's and 00's expansions, but during the 10's expansion, there was never a return to such a level or even to the average productivity growth of near 2 percent of the prior 50 years. Lower productivity growth slows living standard growth and slows wage growth. The causes of the reduced productivity growth are too complex and numerous to delve into here, but may include a shifting industry mix towards services, a reduction in business dynamism, increased concentration in some sectors, insufficient $R \& D$ spending (including at the federal level), problems in the intellectual property regime, insufficient infrastructure and other capital spending, regulatory shifts, and simple limits of growth. In addition, though, it is distinctly possible that the extensive slack in labor markets reduced the need for productivity enhancements during much of the expansion (Seen Moss, Nunn, and Shambaugh 2020 for general discussion of these issues).

It is also clear from the table that the real wage gains for average workers exceeded those for the median worker or low-wage worker, implying a continued faster growth for those at the top of the income distribution. This follows all three prior expansions where average gains exceeded those at the median and the expansions of the 1980s and 2000's where low-wage workers received literally no gains. The lack of gains in the 1980s meant that real wages at the $20^{\text {th }}$ percentile did not exceed their 1979 level until 1998, and the lack of gains in the 2000s 
followed by a drop in the Great Recession meant they did not exceed their 2001 level in real terms until 2016.

Finally, a considerable difference in this expansion was the lower level of price growth and nominal wage growth. While real wages grew faster, as noted above nominal wage growth was consistently lower than prior eras as was price growth.

As noted, this expansion was in many ways divided into a long expansion with extensive slack and then eventually more pressure in the labor market. This is seen most clearly looking at wage growth across different parts of the income distribution. Figure 7 shows real wages indexed to 2007 across the income distribution. During the recession itself, there was a small tick up across the wage distribution likely attributable to composition effects as so many workers were laid off, in many cases leaving higher wage or higher productivity workers still employed. In the early years of the expansion, when there was extensive labor market slack, real wages for both the bottom quintile and the median worker were actually falling. Had the expansion ended in 2014, real wages would have fallen during this expansion for both groups of workers. During that time, higher income workers and average wages were rising, in some sense masking the struggles at the bottom of the distribution.

Later in the expansion, though, real wages began to grow for all workers. Median wages began rising in 2012, and wages at the bottom of the distribution began rising in 2015 . For the last five years of the expansion, in fact, real wages were rising most rapidly for workers at the bottom quintile.

Figure 8 shows this using weekly earnings (not wages) for the tenth percentile and the ninetieth percentile of the distribution. In the early years of the recovery, earnings fell for 
workers at the bottom, and were stagnant for workers at the top. In the final years of the recovery, though, earnings grew at an annual rate of around 1 percentage point faster at the bottom than at the top. For the business cycle as a whole, weekly earnings grew at an annual rate of 1.4 percent for those in the $90^{\text {th }}$ percentile, 0.9 percent at the median, and 1.3 percent at the $10^{\text {th }}$ percentile.

Faster wage growth at the bottom was likely a mixture of many factors, but diminishing labor market slack was almost certainly a crucial force. ${ }^{13}$ Increased minimum wages at the state and local levels also put upwards pressure on wages at the bottom of the distribution in some places. $^{14}$

The boost to wages at the bottom of the distribution mirror those for other often disadvantaged groups in the labor market. Real wages for the median Black worker grew 8 percentage points more from 2015 to 2019 than they did from 2007 to 2015 . For Hispanic workers, growth was 9 points higher. For white workers, it was just 2 points higher. The gap was because the median white worker was seeing gains throughout the recovery and they increased, but not as much, in the later stage. Groups that are often marginalized, though, only saw gains late in the recovery. ${ }^{15}$

\footnotetext{
${ }^{13}$ Clemens and Strain (2017) and Strain (2019) discuss the roles of market forces and institutions play in wage determination.

${ }^{14}$ Wages did increase in states that did not raise their minimum wage, showing the importance of reduced slack in the low-wage labor market. Nunn and Shambaugh (2020) show that states that increased their minimum wage by more than the median increase after 2013 showed notably faster real wage growth from 2010-2018 at the 5, 10, and $20^{\text {th }}$ percentile than those states that made small increases or those that did not increase the minimum wage at all. This was not simply because these places had booming labor markets. In those states with high minimum wage increases, wages at the $5^{\text {th }}, 10^{\text {th }}$, and $20^{\text {th }}$ percentiles substantially outpaced median and even $90^{\text {th }}$ percentile wage increases, while those without large minimum wage gains did not.

${ }^{15}$ See Biu, Famighetti, and Hamilton (2021) for a more detailed discussion of the impact of the Great Recession on Black American's wages and Orrenius and Zavodny (2021) for a discussion of outcomes for Hispanic workers.
} 
A similar dynamic took place with employment. Figure 9 shows the employmentpopulation ratio for prime-age people with less education than a high school degree and for college graduates, indexed to their longer-term average, defined as the average ratio from 1992 until the month before the Great Recession began. In the recession and early years of the expansions, employment for high-school dropouts was further below its longer-run average level than employment for college graduates. By around 2015, both were similarly below their longrun averages. And in the last three or so years of the expansion, the employment rate for highschool dropouts was further above its long-run average than the rate for college graduates. In addition, both the initial decline and the subsequent recovery for the high-school dropout rate were steeper than for college graduates.

Recessions often hit the most economically vulnerable the hardest. A slow recovery also meant little pressure to bring marginalized workers back or lift pay. This was especially problematic because as noted earlier, the short expansion of the 2000s left near zero real wage growth for the workers at the $20^{\text {th }}$ percentile. By 2014, a worker at the $20^{\text {th }}$ percentile was making less than in 2009. Thus, the gains that started in 2015 may have been swift, but in many ways they were making up for years of stagnation for workers at the bottom of the distribution.

As our figures for wages and employment have shown, the least-skilled workers are hit hardest by recessions, but also experienced the strongest relative gains from the hot economy in the final years of the expansion. The same is true for traditionally vulnerable workers.

Figure 10 shows the employment rate for people with disability. It trended down during the Great Recession and for the early years of the expansion. But beginning in 2014, the rate trended upward, as labor market slack was increasingly absorbed. Anecdotes suggest that the 
formerly incarcerated similarly benefited from the tight labor market of the expansion's final years, as well (Strain, 2018). ${ }^{16}$

\section{Policy responses}

At the onset of the Great Recession, monetary policy responded swiftly, with the Federal Reserve beginning to cut rates even before the recession began and then moving them to zero by December of 2008. In addition, the Fed made a series of interventions to try to calm markets. Finally, the Fed used a variety of tools it had not used before ranging from large scale asset purchases (quantitative easing) to forward guidance (promising to keep rates low for an extended period of time), aiming to boost the economy.

Despite these efforts, though, inflation was persistently below the Federal Reserve's target of 2 percent for their preferred inflation measure, the core personal consumption expenditures price index. With the exception of a handful of months in early 2012 and mid 2018 when the year over year changes were 2.1 percent, inflation was below target the entire time. Certainly by the last few years of this expansion, the Federal Reserve was quite close to its goals, with inflation between 1.5 and 2.0 percent and the unemployment rate below 5 percent. That said, it seems it was fairly far from full employment for an extended period of time and yet always missed inflation on the lower side of its target.

In anticipation of inflation moving higher, the Federal Reserve began to tighten monetary policy — or, more precisely, to reduce the amount of monetary accommodation — beginning in

\footnotetext{
${ }^{16}$ See Bengali et. al (2021) for a discussion of outcomes for individuals with disabilities and Finlay and MullerSmith (2021) for a discussion of the employment outcomes for justice-involved individuals.
} 
2015. Initially, the Federal Reserve Open Market Committee (FOMC) anticipated raising interest rates three times in 2015 and four times in 2016. As it turned out, as the economy slowed, the dollar appreciated, and price growth remained low (all possibly in part due to the anticipated coming increases), actual rate increases did not begin until one rate hike at the end of 2015, and there was only in 2016 as well. The FOMC continued raising rates as the amount of slack in the economy lessened. It raised rates seven times from 2017 to 2019, moving the federal funds rate much closer to what the committee considered neutral.

Interestingly, despite the fact that the recovery was continuing and the unemployment rate was below the CBO's estimate of the natural rate, the FOMC cut rates three times in 2019, beginning in August. The rationale for the rate cuts was that the economy was still showing room for growth, with little price pressure, but growth was slowing and financial markets were showing signs of stress. The question of whether these policies would have successfully engineered a soft landing and continued growth was cut short by the COVID-19 pandemic.

Fiscal policy was far more variable. Early in the recession there were a series of attempts to support the economy, first with direct rebate checks in early 2008 and then again with the American Recovery and Reinvestment Act (ARRA). These policies provided households and states with considerable funds, and ARRA included large scale direct spending as well. ARRA was successful in reducing the severity of the recession and supporting the economy during the expansion. Critics argue that aspects of its composition were ill suited to the economy's needs, and supporters argue that it was too small.

While there were a number of policies passed over the remaining years that could be considered fiscal stimulus (ranging from various unemployment insurance extensions to the payroll tax cuts), on net, fiscal policy turned contractionary by 2011 . This was due to the 
expiration of ARRA funds, eventually due to previous tax cuts expiring, fiscal tightening at the state and local level, and due to consistent efforts in Congress to pivot to fiscal austerity, blocking efforts by the Obama administration to pass additional stimulus. In our view, the Republican Congress's insistence that fiscal policy tighten, and its refusal to pass additional stimulus, was a significant policy mistake. As shown in Sheiner and Ng (2019), the shift to fiscal tightening was far deeper and faster than one would normally expect given economic conditions at the time. Beyond macroeconomic policy, many other factors likely affected the pace of the recovery. Shifts in demographics were almost certainly a drag (Shambaugh, 2016), and a range of other regulatory or microeconomic policies in education, healthcare, environment, and technology, likely had both positive and negative effects, but they run beyond the scope of this paper.

Fiscal policy shifted after the election of President Trump. The Republican Congress was now willing to relax spending caps that had limited fiscal policy during the Obama years, and in 2017 it passed the deficit-financed Tax Cuts and Jobs Act. These policies increased aggregate demand and provided a tailwind for the economy.

In sum, fiscal policy was expansionary at the onset of the Great Recession, but became contractionary when there was still a considerable output gap and significant labor market slack. Fiscal policy shifted closer to neutral by 2015-2016. Then, policy became much more expansionary even as the amount of slack in the economy lessened in 2017-19. 


\section{Discussion and conclusions}

At the time of this writing, the business cycle front of mind is the Pandemic Recession, which ended the expansion from the Great Recession. Comparing the likely path of the current recovery with the recovery following the Great Recession offers several important conclusions and lessons for the future.

First, it takes an economy much longer to heal from a downturn caused by or associated with a financial crisis. The recovery from the Great Recession was much longer than the three that came before it in part because the economy had to work through the structural imbalances in financial and housing markets that led to the recession, along with households needing time to bring their balance sheets back to health.

The absence of these sorts of imbalances on the eve of the Pandemic Recession likely will mean that the recovery from it will be more rapid than from the Great Recession, something that would have seemed remarkable to many economists when the pandemic struck this spring given the speed and depth of the downturn in March and April of 2020. While this may be true for the aggregate economy, it is important to note that many households entered the pandemic recession with little or no financial cushion, leaving them in substantial distress when the shock hit. ${ }^{17}$

Going into a recession with labor market slack significantly exacerbates a recession's damage to typical and low-income households. The slack in labor markets in 2007 meant the recovery from the Great Recession got off to a worse start than would otherwise have been the case. Again, this contrasts with the Pandemic Recession, in which the labor market was at or

\footnotetext{
${ }^{17}$ See Zilliak (2021) for further discussion.
} 
near full employment at its outset. In addition, it's important not to underestimate the role of slack in today's macroeconomic environment. During the expansion following the Great Recession, the economy was still absorbing slack when the unemployment rate was below 5 percent, a feature that surprised many economists and policymakers. Even in the first full calendar year of the recovery, the question of whether the Great Recession had increased structural unemployment was being actively debated. When the unemployment rate fell below 6 percent in 2014, concern about the Fed allowing an inflationary environment were commonly voiced (Strain, 2014). With hindsight, we now know that the root of these overblown concerns was underestimating the extent of slack.

The slow-and-steady recovery from the Great Recession led many to express concerns about hysteresis. ${ }^{18}$ These concerns also seem not to have come to pass. The workforce participation rate for prime-age people fully (or nearly fully) recovered its pre-recession level. Long-term unemployment was a major concern during the recovery from the Great Recession. ${ }^{19}$ But the number of long-term unemployed workers was below its pre-recession level when the pandemic hit this spring. The length of the expansion likely helped avoid short-term cyclical problems from becoming structural problems in the labor market.

Another lesson from the recovery from the Great Recession is that low-wage workers and low-income households are relatively more sensitive to the business cycle. These groups were hit harder by the downturn, and the gains in the early years of the recovery did not reach them. But they also benefited disproportionately from the tightening labor markets that characterized the

\footnotetext{
${ }^{18}$ See, for example, Hassett and Strain (2014) and Summers (2014). Hysterisis refers to a situation in which a temporary economic shock creates longer-term, more-lasting economic problems. For example, when workers who are unemployed due to a drop in aggregate demand either leave the labor market (depressing participation) or are more difficult to employ due to their skills deteriorating during a long period of unemployment.

${ }^{19}$ See, for example, Strain (2014).
} 
recovery's final years. Had the recovery ended earlier, those benefits would not have materialized. The final years of the recovery indicate that tight labor markets are the most effective jobs and wages program in the government's policy arsenal. In addition, conventional measures of income inequality show that its growth has stagnated or even declined since the Great Recession began (Strain, 2020).

If the goal is to ensure that the benefits of an expansion reach low-wage workers and lowincome households, then fiscal and monetary policy need to respond aggressively to downturns and to allow expansions to continue until there is tangible evidence of supply constraints and inflationary forces taking hold.

The Great Recession was the most substantial shock to hit the U.S. economy since the Great Depression, and will likely be remembered as a more severe and lasting downturn than the Pandemic Recession. While aggressive policy responses likely prevented a second depression, they were not enough to lift growth to high enough rates to bring the economy back to full health quickly. The expansion that followed was the longest on record. Its length allowed it to evolve from an expansion characterized in its early years by too much slack, millions out of work, and tepid wage growth into an expansion where, in its latter years, gains were broadly shared and often-marginalized groups saw their labor market outcomes improve. 


\section{References}

Addo, Fenaba R. and William A. Darity, Jr., "Wealth, Race, and the Working Class from 20102019," ANNALS of the American Academy of Political and Social Science, forthcoming.

Bengali, Leila, Mary C. Daly, Olivia Lofton, and Robert G. Valletta, "The Economic Status of People with Disabilities and their Families since the Great Recession," ANNALS of the American Academy of Political and Social Science, forthcoming.

Bernstein, Jared, "The Importance of Strong Labor Demand," The Hamilton Project, Policy Proposal 2018-03, February 2018.

Biu, Ofronama, Christopher Famighetti, and Darrick Hamilton, "The Impact of Recessions on the Black Working and Professional Classes: Wages, Essential Work, and Occupational Safety Risks," ANNALS of the American Academy of Political and Social Science, forthcoming.

Clemens, Jeffrey and Michael R. Strain, "Estimating the Employment Effects of Recent Minimum Wage Changes: Early Evidence, an Interpretative Framework, and a PreCommitment to Future Analysis," NBER Working Paper Series, no. 23084, January 2017.

Daly, Mary C. and Bart Hobijn, "Composition and Aggregate Real Wage Growth." American Economic Review, vol. 107, no. 5, 2017.

Finlay, Keith and Michael Mueller-Smith, "Justice-Involved Individuals in the Labor Market since the Great Recession," ANNALS of the American Academy of Political and Social Science, forthcoming.

Hassett, Kevin A. and Michael R. Strain, "Worksharing and Long-Term Unemployment," in Jared Bernstein editor, Full Employment Project, Center on Budget and Policy Priorities, April 2014.

Lazear, Edward P. and James R. Spletzer, "The United States Labor Market: Status Quo or A New Normal?” NBER Working Paper Series, no. 18386, September 2012.

Moss, Emily, Ryan Nunn, and Jay Shambaugh. "The Slowdown in Productivity Growth and Policies That Can Restore It." The Hamilton Project, Brookings Institution, Washington, DC (2020).

Nunn, Parsons, and Shambaugh (2018), "The Geography of Prosperity” in Place Based Policies for Shared Economic Growth edited by Jay C. Shambaugh and Ryan Nunn, The Hamilton Project, September 2018. 
Nunn, Ryan, Jana Parsons, and Jay Shambaugh. Labor Force Nonparticipation: Trends, Causes, and Policy Solutions. The Hamilton Project, 2019.

Nunn, Ryan and Jay Shambaugh, "Whose wages are rising and why?," Policy 2020, The Brookings Institution, January 21, 2020.

Orrenius, Pia and Madeline Zavodny, "How Foreign- and U.S.-Born Latinos Fare during Recessions and Recoveries," ANNALS of the American Academy of Political and Social Science, forthcoming.

Russ, Kathryn and Jay C. Shambaugh (2019), "Education and Unequal Regional Labor Market Outcomes: the persistence of regional shocks and employment responses to trade shocks," paper presented at the Boston Federal Reserve conference, A House Divided: Geographic Disparities in Twenty-First Century America, October 2019.

Jorda, Oscar, Moritz Schularick, Alan M. Taylor, (2015) "Sovereigns versus Banks: Credit, Crises, and Consequences," Journal of the European Economic Association, Volume 14, Issue 1, 1 February 2016, Pages 45-79.

Schanzenbach, Diane Whitmore, Ryan Nunn, Lauren Bauer, and Audrey Breitwieser, "The Closing of the Jobs Gap" The Hamilton Project, August 4, 2017.

Shambaugh, Jay C., "How Should We Think About this Recovery?" speech at Macroeconomic Advisers' 26th Annual Policy Seminar, September 16, 2016. https://obamawhitehouse.archives.gov/sites/default/files/docs/20160914_cea_shambaugh _macroadvisers.pdf

Sheiner, Louise, and Michael Ng. 2019. "How Stabilizing Is Fiscal Policy?” In Recession Ready: Fiscal Policies to Stabilize the American Economy, edited by Heather Boushey, Ryan Nunn, and Jay Shambaugh. Washington, DC: The Hamilton Project and the Washington Center on Equitable Growth

Strain, Michael R., “A Jobs Agenda for the Right,” National Affairs, no. 18, winter 2014.

Strain, Michael R., "On balance, a little inflation is better than a lot of unemployment," The Washington Post, October 7, 2014.

Strain, Michael R., "Protect the Gains Made by Low-Skilled Workers," Bloomberg, November 1, 2018.

Strain, Michael R., "The Link Between Wages and Productivity Is Strong," in Melissa S. Kearney and Amy Ganz editors, Expanding Economic Opportunity for More Americans, The Aspen Institute, 2019.

Strain, Michael R., The American Dream Is Not Dead: (But Populism Could Kill It), Templeton Press, 2020. 
Summers, Lawrence H., "U.S. Economic Prospects: Secular Stagnation, Hysteresis, and the Zero Lower Bound," Business Economics, vol. 49, 2014.

Ziliak, James P., "Recent Trends in the Material Well Being of the Working Class in America," ANNALS of the American Academy of Political and Social Science, forthcoming. 


\section{Tables and Figures}

\section{Table 1: Macroeconomic Indicators for 30 Years of Business Cycles}

$\begin{array}{lllll}\text { Recession } & \underline{1981-82} & \underline{1991} & \underline{2001} & \underline{2007-2009}\end{array}$

$\underline{\text { Recession Indicators }}$

Cumulative job loss (millions)

$$
-2.8
$$

$$
-1.5
$$

$-2.6$

$-8.6$

Peak real GDP loss \%

$$
-2.6 \%
$$

$-1.4 \%$

$-0.4 \%$

$-4.0 \%$

Peak unemployment rate increase

2.3

2.0

5.0

Prime-age emp-pop change (pp)

$-0.9$

$-1.6$

$\underline{\text { Recovery Indicators }}$

Months to reach prior peak employment

Quarters to reach CBO natural UR
28

26
32

25
47

19
77

39

Notes: Cumulative job loss measured from start of recession until employment trough using nonfarm payroll employment from the Bureau of Labor Statistics. Prime-age emp-pop is prime-age (25-54) employment to population ratio. Real GDP measured in chained 2012 dollars from the Bureau of Economic Analysis. 
Table 2: Macroeconomic Indicators for Recent Business Cycles

\begin{tabular}{|c|c|c|c|c|}
\hline Recession & $\underline{1981-1991}$ & $\underline{1991-2001}$ & $\underline{2001-2007}$ & $\underline{2007-2019}$ \\
\hline Length of following expansion (months) & 108 & 128 & 81 & 147 \\
\hline Cumulative real wage gains (all workers) & $5.0 \%$ & $17.7 \%$ & $5.2 \%$ & $15.3 \%$ \\
\hline $\begin{array}{l}\text { Average annual real wage gains (all } \\
\text { workers) }\end{array}$ & $0.5 \%$ & $1.6 \%$ & $0.8 \%$ & $1.2 \%$ \\
\hline Average labor productivity growth & $1.7 \%$ & $2.1 \%$ & $2.8 \%$ & $1.3 \%$ \\
\hline Average median real wage growth & $0.2 \%$ & $1.3 \%$ & $0.6 \%$ & $0.6 \%$ \\
\hline Average 20th percentile real wage growth & $-0.2 \%$ & $1.7 \%$ & $0.0 \%$ & $1.0 \%$ \\
\hline Nominal annual average wage growth & $4.3 \%$ & $3.7 \%$ & $3.2 \%$ & $2.8 \%$ \\
\hline Inflation rate (PCEPI) & $3.8 \%$ & $2.0 \%$ & $2.3 \%$ & $1.5 \%$ \\
\hline
\end{tabular}

Notes: This table measures changes in wages and prices over full business cycles (i.e., recessions and the expansions that followed them), using annual data for the years shown. Wage data for different parts of the wage distribution come from the Economic Policy Institute's State of Working America Data Library. The original data are from the Bureau of Labor Statistics. We reflate the EPI data using the CPI-U-RS, and deflate it using the PCE. Productivity data uses quarterly data over the span of the business cycle. Authors' calculations. 
Figure 1: The Evolution of Employment Over the Business Cycle

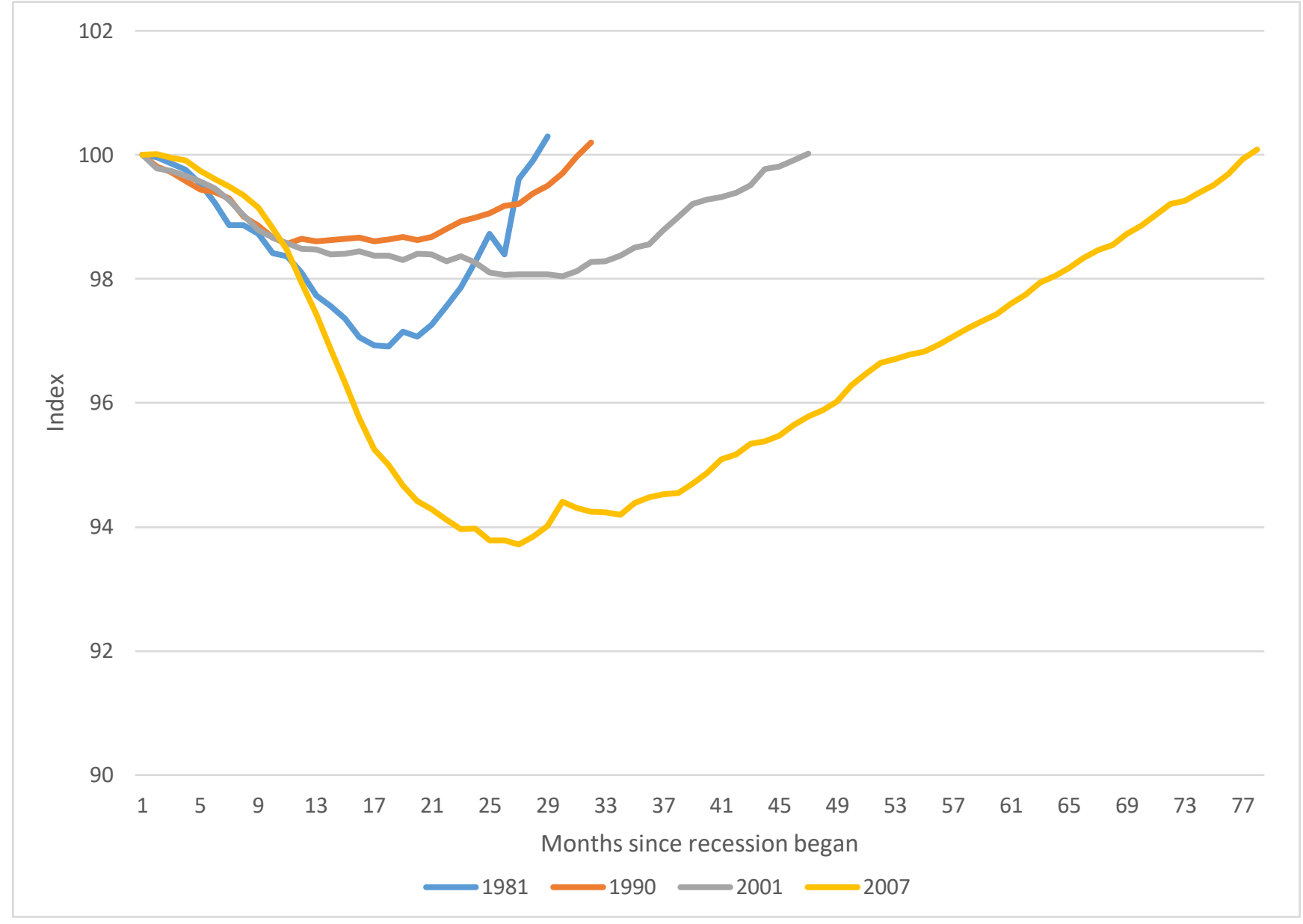

Notes: Authors' caculations using nonfarm payroll employment data from the Bureau of Labor Statistics. The level of employment is indexed to 100 in the first month of the recession. Each line represents a different business cycle. 
Figure 2: Net Worth of Households and Nonprofit Organizations

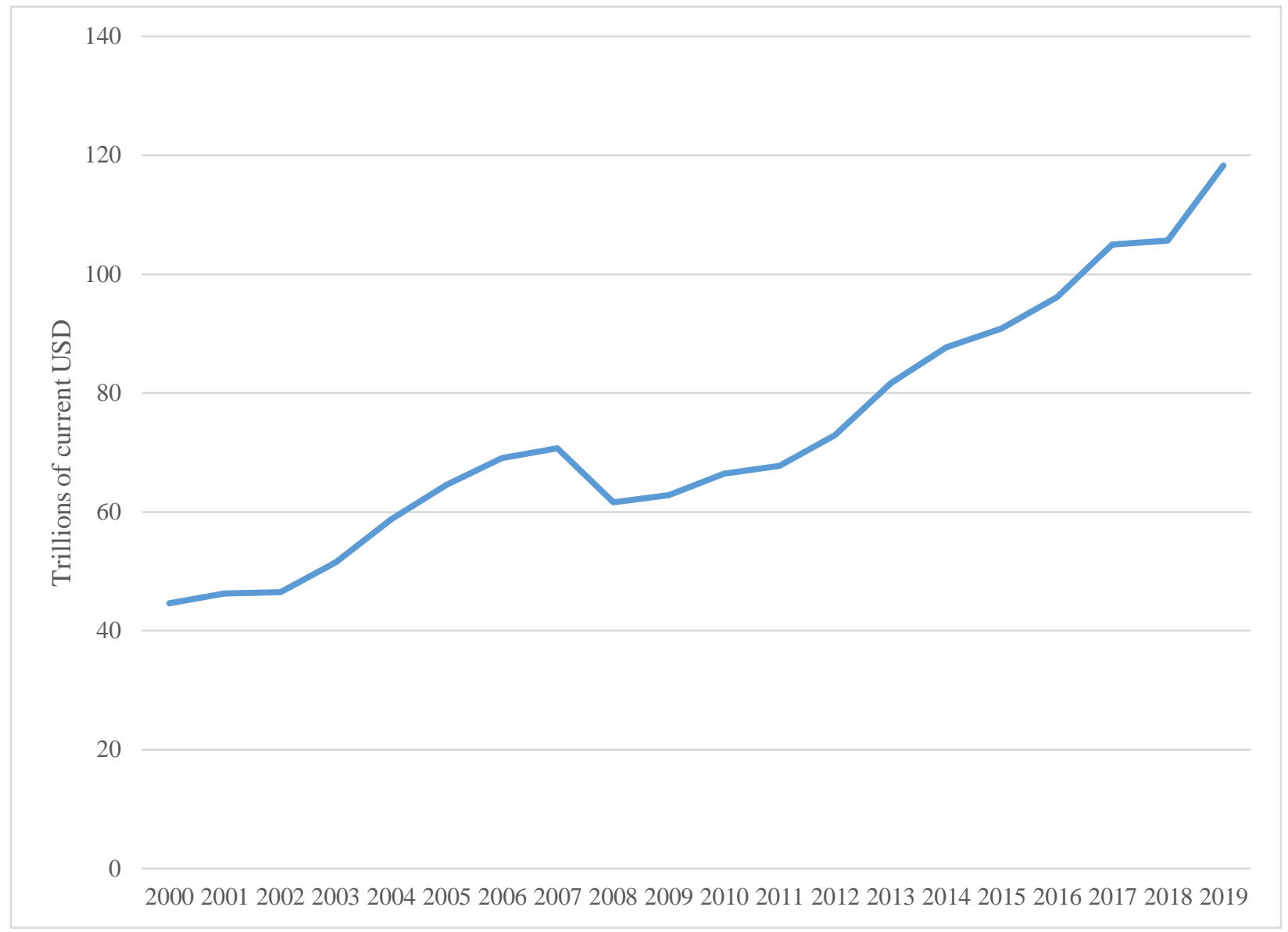

Notes: The figure shows the net worth of households and nonprofits in trillions of current dollars. The data are from the Federal Reserve Board, retrieved from FRED, and are charted by the authors. 
Figure 3: Difference Between the Unemployment Rate and its Natural Rate

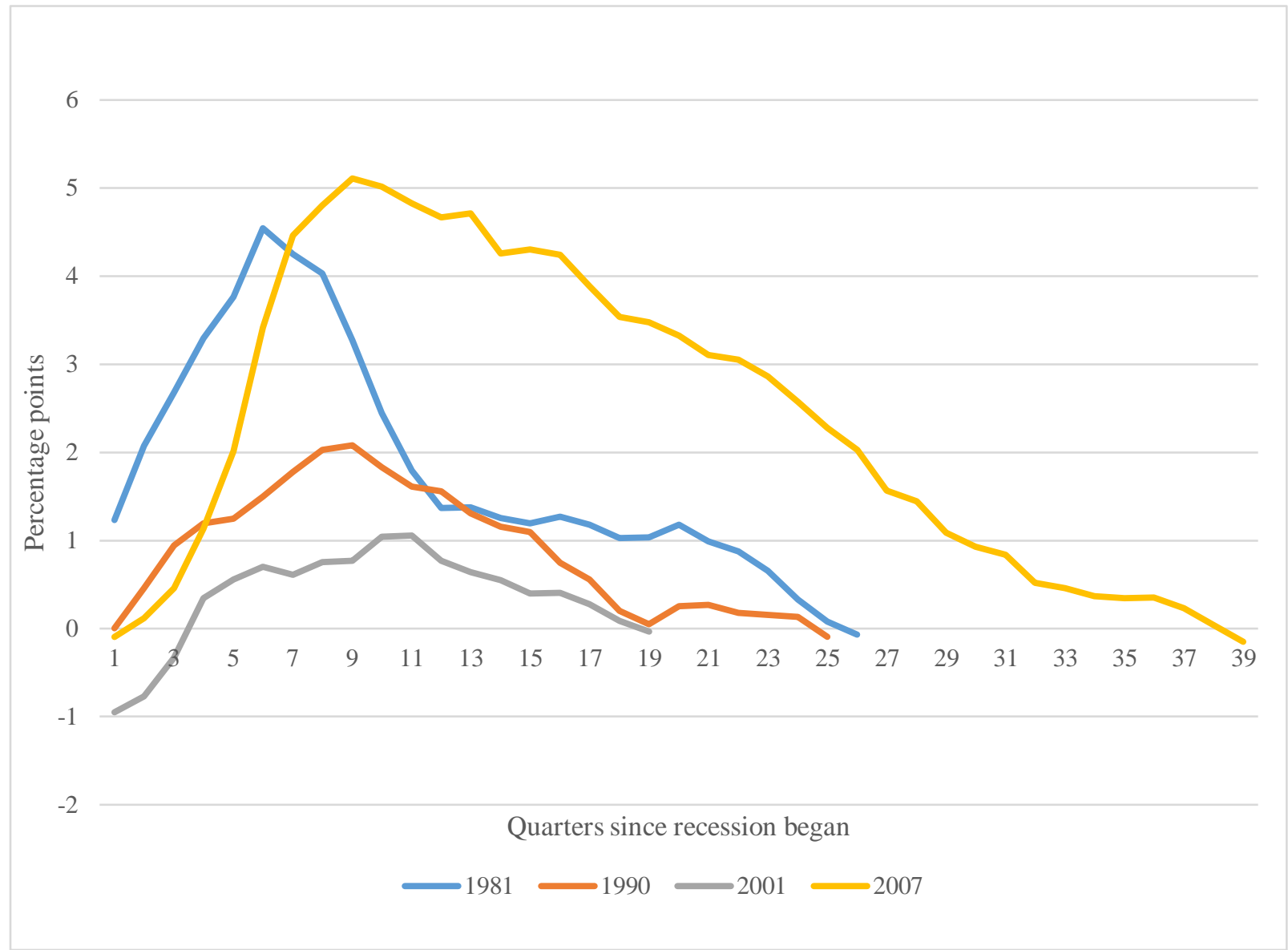

Notes: This chart shows the difference between the unemployment rate and the Congressional Budget Office's estimate of the long-term natural rate of unemployment. Each line represents a different business cycle. Authors' calculations. 
Figure 4: Prime-Age Labor Force Participation Rate

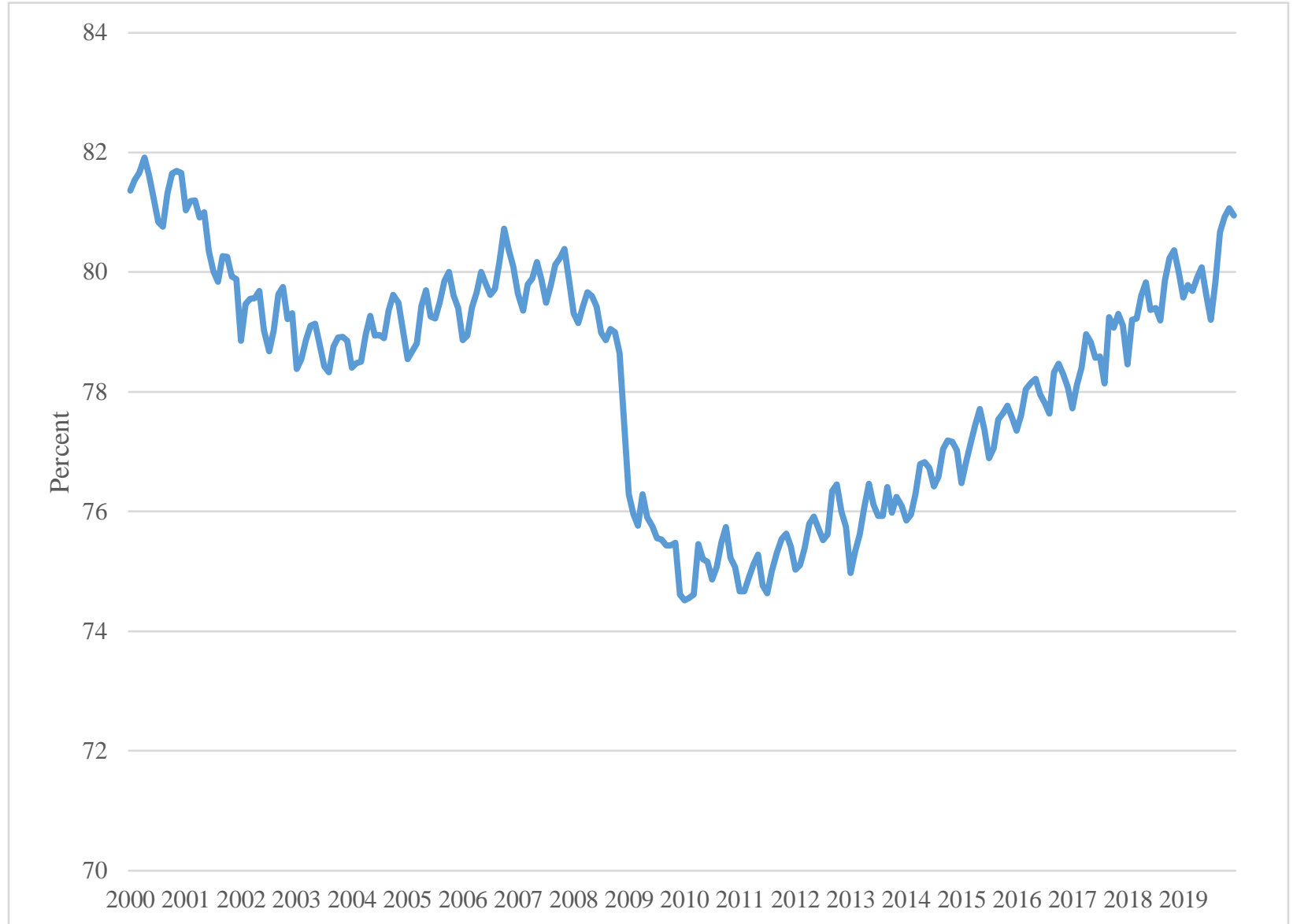

Notes: Labor force participation rate for people ages 25 to 54 years. Bureau of Labor Statistics data, retrieved from FRED, charted by the authors. 
Figure 5: Monthly Job Growth and Working Age Population Growth

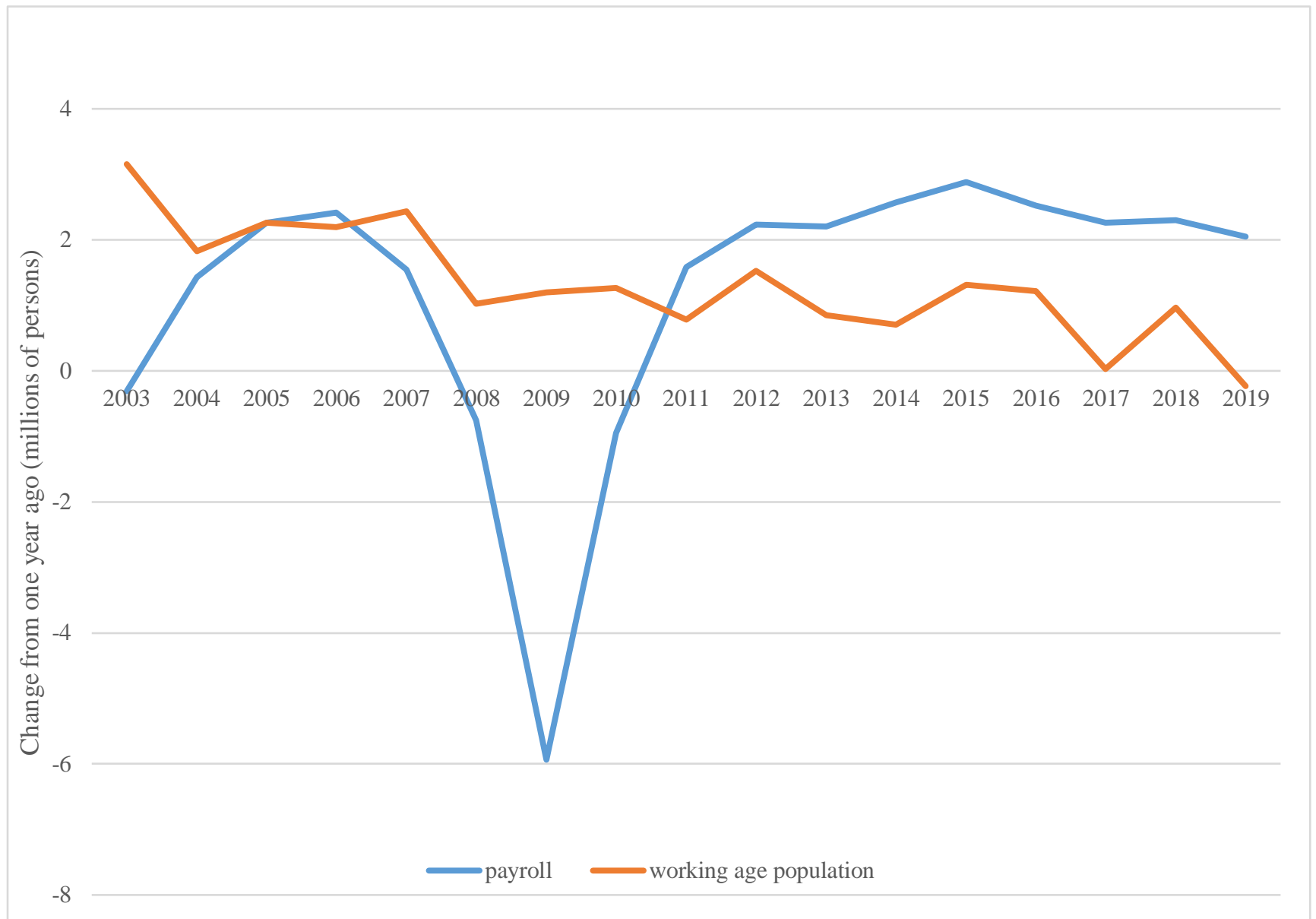

Notes: Population ages 16 and over and nonfarm payroll employment data from the Bureau of Labor Statistics, retrieved from FRED. Authors' calculations. 
Figure 6: Annual Growth in Average Wages for Nonsupervisory Workers \& PCE Inflation

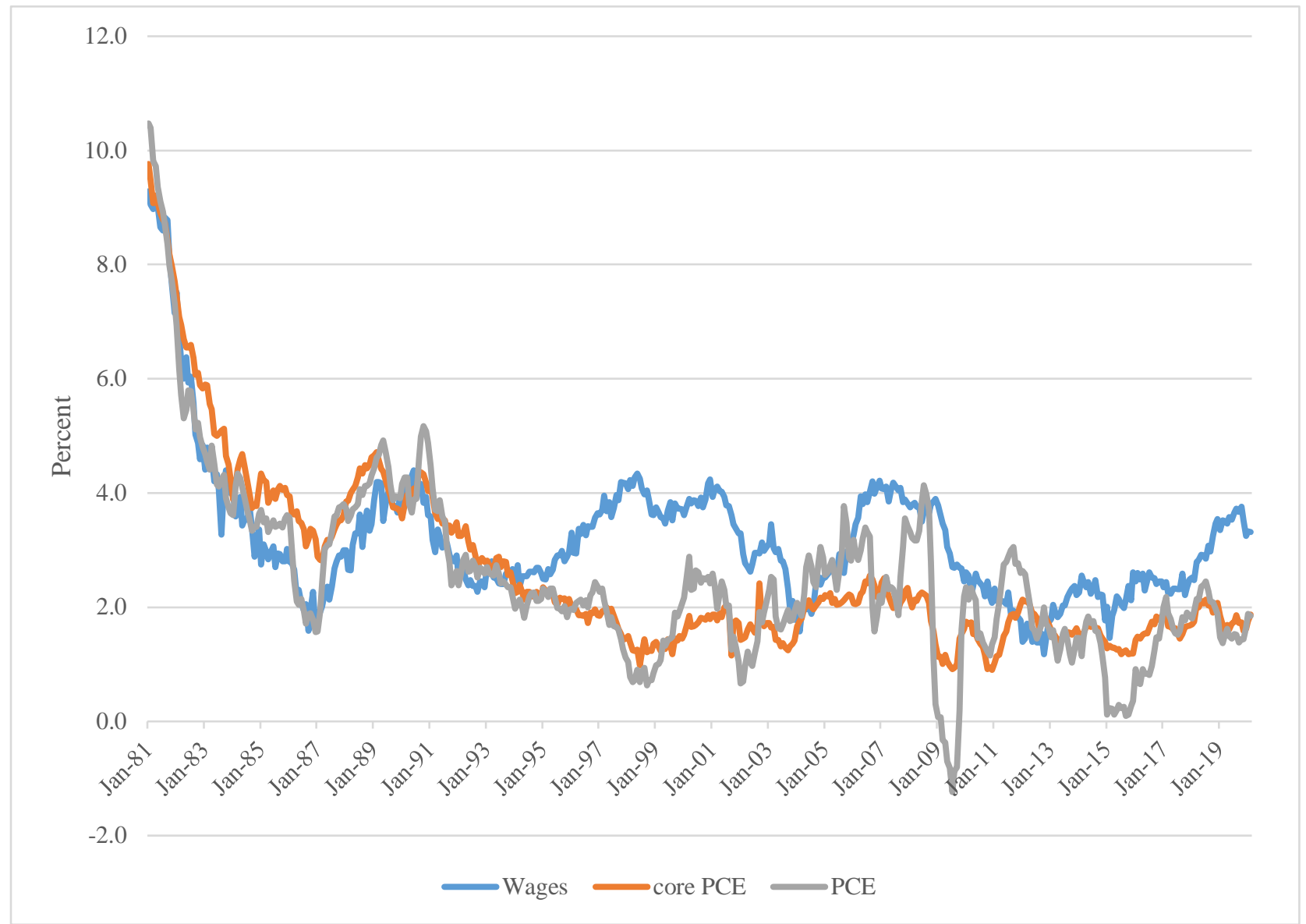

Notes: Annual growth rate of average hourly earnings for production and nonsupervisory workers, the PCE, and the PCE excluding food and energy prices ("core" PCE). Wage data are from the Bureau of Labor Statistics and price data are from the Bureau of Economic Analysis, all retrieved from FRED. Authors' calculations. 
Figure 7: Growth in Real Hourly Wages at Various Percentiles

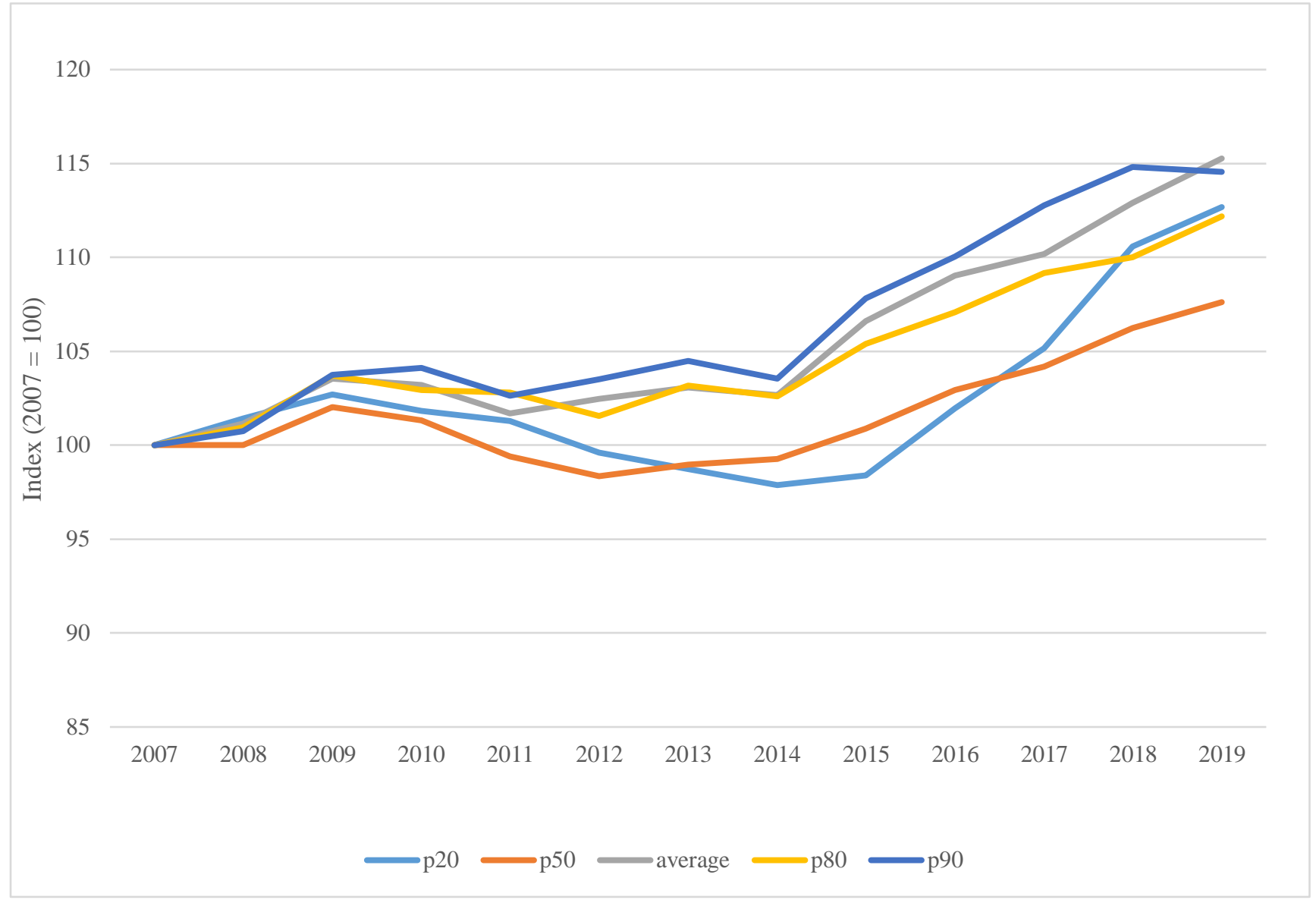

Notes: Wages at different percentiles, and average wages, indexed to 2007. Wages are from the Economic Policy Institute's State of Working America Data Library. Original data from the Bureau of Labor Statistics. Authors' calculations, including reflating the EPI data using the CPI-U-RS and then deflating them using the PCE. 
Figure 8: Annual Growth Rate of Real Weekly Earnings

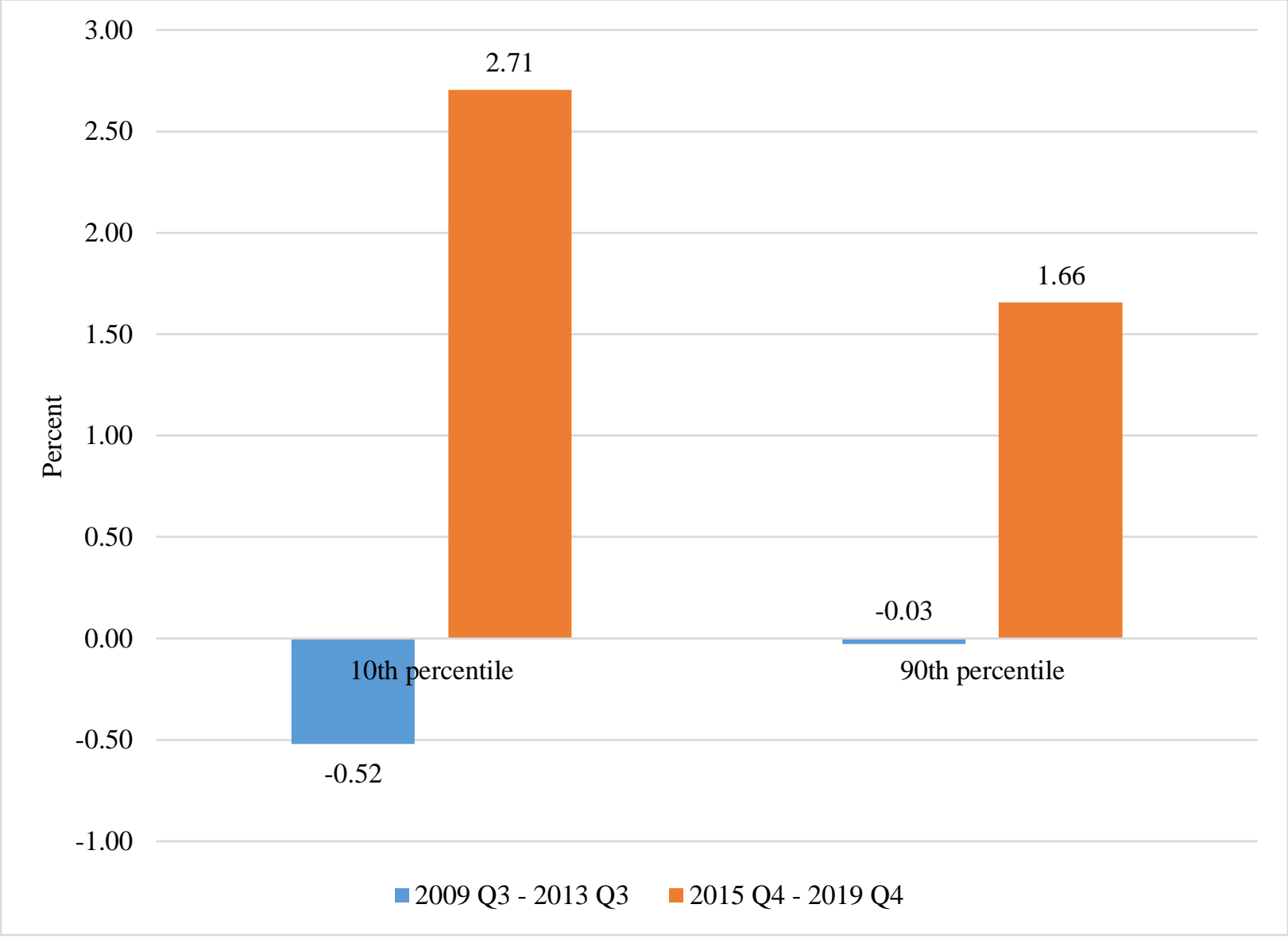

Notes: Authors' calculations using Bureau of Labor Statistics data on usual weekly nominal earnings, retrieved from FRED, and deflated using the PCE. 
Figure 9: Prime-Age Employment Relative to Its Long-Term Average

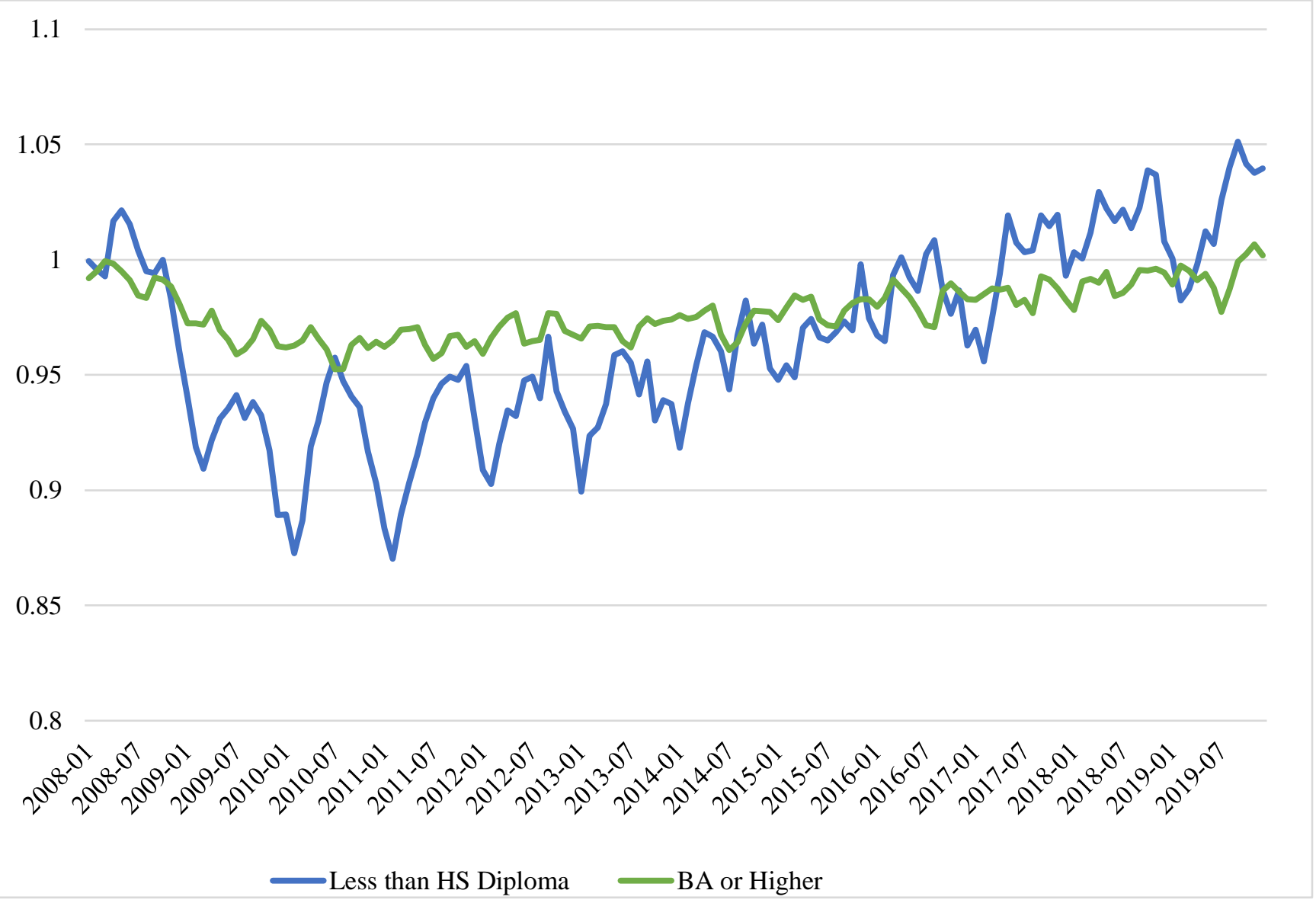

Notes: Employment-population ratio for each education group relative to its average from January 1992-November 2007. Authors' calculations using the Current Population Survey. 


\section{Figure 10: Employment Rate for People with Disabilities}

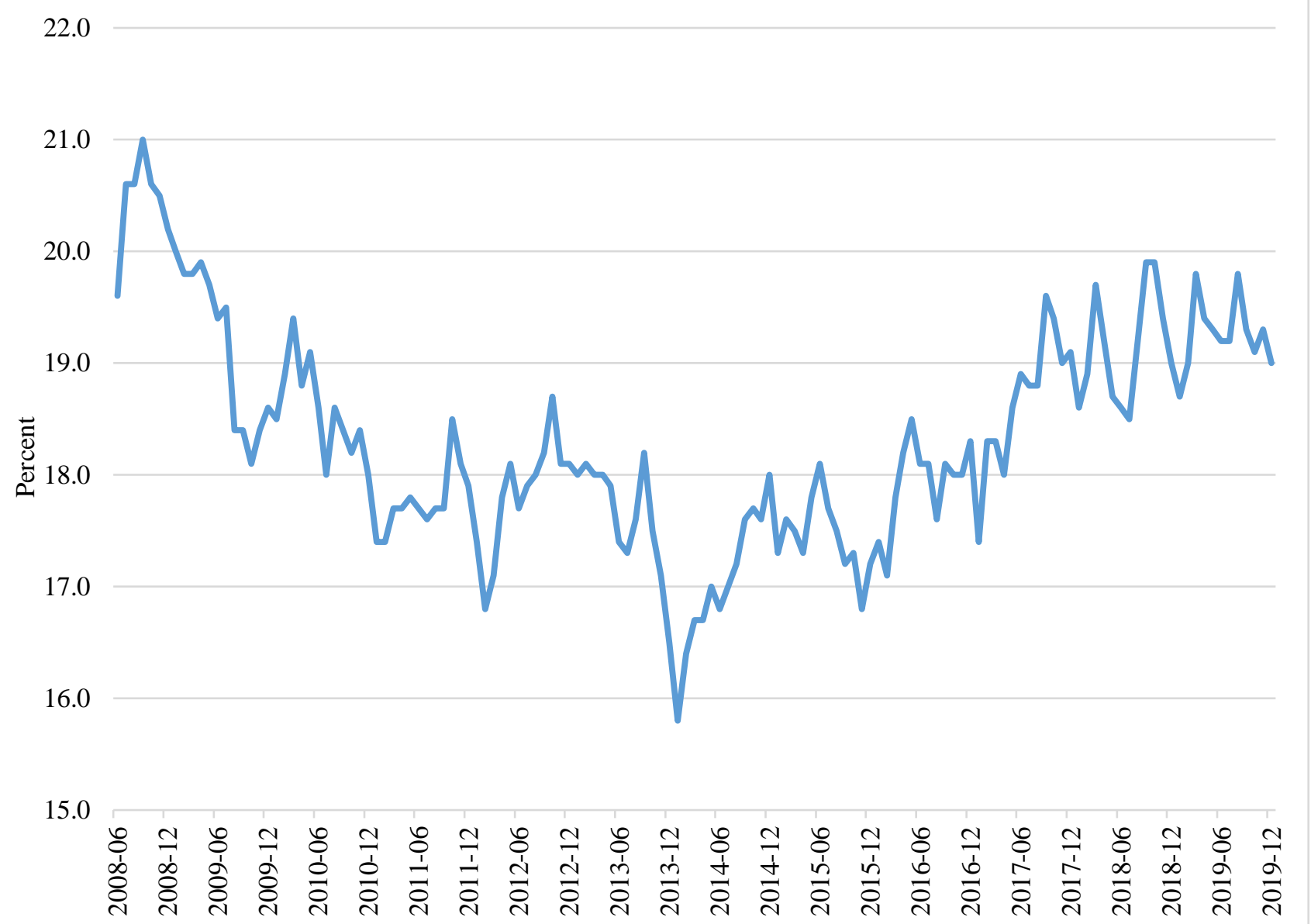

Notes: Employment-population ratio for people with a disability, retrieved from FRED, and charted by the authors. 